\title{
WAITING FOR GODOT AND THE ZOO STORY: A CRITICAL PERSPECTIVE TOWARDS POSTMODERN CIVILIZATION
}

\author{
Srinewas Prasad Yadav \\ Department of English, TU, Thakur Ram Multiple Campus, Birgunj, Nepal \\ E-mail: academicvoices2o1o@gmail.com
}

\begin{abstract}
This paper is an attempt out of my living mode of experience in the contemporary society, academic learning, and my teachers' contribution in imparting epistemological meaning of life and the world to me, to explore the implication of globalization and its different layers of deformities accelerating absurdities, challenging ethical values encompassed with existentialism, nihilism and Charles Darwin's phrase 'struggle for existence', and how the plays-Waiting for Godot and The Zoo story are applicable in the postmodern society-decentring its rationality, faith, love, mutual-understanding and seeking metaphysical protection: giving birth to skepticism everywhere, to show how the contemporary civilization is on the track of Estragon and Vladimir, Pozzo and Lucky, Jerry and Peter respectively and, why the colonized Man opt best for 'suicide'.
\end{abstract}

\section{Key words}

Epistemological meaning of life; globalization; absurdities; struggle for existence

\section{Introduction}

Waiting for Godot and The Zoo Story can respectively be categorized under Absurdist plays candidly represent the postmodern civilization. Absurdist plays give artistic meaning to Albert Camus' philosophy that "Life is inherently without meaning". Albert Camus and Jean - Paul Sartre view a human being as an isolated existent who is cast into an alien universe, to conceive the human world as possessing no inherent truth, value or meaning and to represent human life in its fruitless search for purpose and significance and nothingness where it must end as an existence which is simultaneous anguished and absurd.

Waiting for Godot is a tragicomedy in two acts written by Beckett (1954). It is about two tramps who are madly in search of metaphysical protection, which is, as a matter of fact, presents their complexities. The Zoo Story is a one act play written by Edward Albee in which two characters- Jerry and Peter present way of postmodern civilization through their 
irrational talk. Postmodern is a package of beliefs in metaphysics, epistemology, Ethics and Politics associated by a group of writers such as Michael Foucault, Stanley fish, and Jacque Derrida. Postmodernism is a deep skepticism in Epistemological beliefs. A world of today is optimally creeping into the features of Peter and Jerry, Estragon and Vladimir.

\section{A critical perspective towards postmodern civilization}

Eclectic nature of postmodernism where Nietzschean philosophy "Nothing can be taken for granted" and Jean-francois Lyotard's definition of postmodernism as "incredulity towards metanarratives" gave an impetus to dubious nature of everything. In a world of today, Darwin's Phrase - 'struggle for existence' propelled Existentialism, no doubt, if it results in nihilism. If we see in the characters of Pozzo and Lucky in the play Waiting for Godot and in the play- The Zoo Story the characters of Peter and Jerry, we come to know how their futile aim lead them to frustration and left them anguished. Being a minimalist-Beckett has adopted the circular mode to capture "more in less", the cause of pain and suffering of being in the chaotic world - a world full of mess. The repetition of - nothing to be done, I am going, I don't know why I don't know, nothing is certain, use your intelligence, shows pessimistic view of characters. We see that components of hope and despair, comic and tragic are blended with. Two tramps - Estragon and Vladimir are waiting for Godot whom they have neither ever met nor ever talked. Their conversation is a projection of irrationalism.

Godot is an unidentified person whom they are eagerly waiting for 'metaphysical protection' but their waiting come to end with nothingness. The postmodern civilization instigated by the motive of commercial mechanism is so much so busy that they are dead- in-life. Modern civilization is sick, no particular purpose, struggling in night as we find in the poem- The Scholar Gipsy of
Matthew Arnold where Gipsy utters- Before this strange disease of modern life, With its sick hurry, its divided aims, Its heads o'ertax'd, its palsied hearts was rife-

In the first act, Estragon utters-nothing to be done, and also at one point being exasperated with his life-nothing happens, nobody comes, nobody goes, and it is awful. Materialism has galloped human spirit. It is rooted in the society, has made the civilization blind without knowing the fact. As in The zoo Story animals are divided by bars similarly, in the zoo of ours, men are divided by socio-economic system. In the act first of the play-Waiting for Godot, Pozzo manipulates lucky-stop! (Lucky stops) forward! (Lucky advances) stop! (Lucky stops) think! In a world of today, the so-called civilized society is rotten from within; value of a being is lost. The cook killed the dog because of a 'crust of bread' and jerry kills Peter for a 'bench' to which Peter's prestige is clung. The play ends from where it has started. The postmodern civilization has become cunning, talented in futile and pointless discussion, initiated illogically causing pain and agony culminated in- suicide. The irony of life is that one does not get completely what one desires, though the very person's thinking makes him great for nothing. More talks doesn't surely prove you great and minimalist is unlike that. A man with material comfort has vanity in conspicuous consumption. In the zoo story, jerry punches Peter again and again to force him to talk to him but Peter ignores. He doesn't want to leave his bench. Consequently, they get ready to fight. The communication gap between them brought about aloofness and estrangement culminating into the death of Peter. Man comes to an end in prospect of tomorrow. Vladimir and Estragon's waiting caused them to hang themselves with a 'bit of rope' we will hang ourselves tomorrow, reason: to be saved by Christ-Metaphysical protection. The overvaulting ambition to achieve something for the better future brings damnation as we find in Dr. Faustus's absurdity. Macbeth's over whelming ambition kindled by Lady Macbeth dragged him to 
death and the latter became so mental that she lost her patience and peace of mind and had to face tragic death. Today's people unlike Estragon and Vladimir are hovering around money selling their soul in.

Dr. Faustusean style to live capitalistic Mode of life and to call Him to their mind if in dire need: means have been opportunist making frantic effort blindly to throw dust into eyes of Him. Men are totally involved in a play of pretence, showing their irrationalism, ending with torment. Uncertainty is lurking everywhere and in everything. Today's men are rich in the play of languages but black from within. At one point in the play Waiting for Godot (act two), Lucky weeps when Pozzo says to kill him-the best thing would to kill them (creatures like lucky). Lucky is oppressed and Pozzo is oppressor.

Lack of communication, and fragmentation from self and society force the anguished heart to relieve from this callous world who does not understand the gash of soul ultimately seek leave from this world. Suicide due to life being ultimately meaningless and therefore either too boring or too painful. Bench is a bone of contention for peter to face tragic death. Greed instantly in a very short time draws the man. Dr.Faustus had to face tragic death. He, a talented intellectual, a sound magician, thought himself a "mighty god", desired to "gain-deity" and to make impossible-possible, sold his soul to Lucifer for twenty four years written in a bond with his own blood and for that Mephistophilis was put at his service. His absurdity lies here in the fact that enjoyment for tomorrow corroded him, left him for nowhere, confessed his crime, and seeking- metaphysical protection. Transgression of discipline, no matter what sector it has occupied, must inflict punishment to. Globalization and postmodernism has made the human being machine, unable to feel throbbing of heart, indifferent to mankind and Nature. 'Holier than thou attitude' mind-set has enhanced the limitation of communication gap. A sufferer struggles for his survival but imposer leaves the very person peace nowhere. The society worships those who are materially rich, no bleeding heart, eavesdropper, no matter if they are thumbprint. 'Silence' is exploited and 'trumpeting' is heralded. Lucky stands for silence who is eventually thought to be killed by Pozzo. Jerry forcefully wants to come closer to Peter but Peter doesn't. Peter wants to maintain distance. He has a certain dignity which surprises Jerry. Peter is introvert and he likes to be. His existence lies in his bench, but Jerry confronting for his own existence to talk to erase the streak of communication limitation despite the fact that their struggle for existence underlying no meaning, no certainty but an escape only. In the play The Zoo Story, we see the hot discussion between Jerry and Peter which appear to be quite absurd.

PETER: GET OUT! JERRY: NO.

\section{PETER: I WARN YOU!}

JERRY: Do you know how ridiculous you look now?

PETER: (his fury and self- consciousness have possessed him) it doesn't matter. (He is almost crying) GET A WAY FROM MY BENCH!

Here, the verbal confrontation takes us to the honor of Peter-bench. Life is full of sound and fury, signifying nothing. Nature is never spent and truly speaking unnatural deeds breed unnatural troubles. "The tears of the world are a constant quantity. For each one who begins to weep somewhere else another stops. The same is true of the laugh". It is as statement told to Estragon by Pozzo the hidden meaning of the world.

\section{Conclusion}

In the postmodern world, disappearance of originality, impetus to pretence, rhythmobliteration has made the society hollow. Emotional gash has deserted an indelible stain on humanity. Much of our life is built on 
the hope for tomorrow, yet tomorrow brings us closer to death and is the ultimate enemy. People live as if they didn't know about the surety of death which we have already come to know through the 'Bench' of Peter and 'Godot' for whom Estragon and Vladimir waited for, but gained nothing. Reason downs too late to prevent the doom. This is the absurdity for what the characters fight for their superficial existence which ultimately lead them to nihilistic world. Postmodern men are sick with desires and have infected minds-full of absurdities.

\section{References}

Abrams, M. H. and Harpham G. G. (2016). A Glossary of Literary Terms. Delhi: Cengage Learning India Private limited.

Albee, E. (1959). The Zoo Story. Bareilly: Prakash Book Depot.

Arnold, M. (1853). The Scholar-Gipsy. Arnold's poems, (1853). Longmans: England

Beckett, S.B. (1954). Waiting for Godot. Delhi: Surjeet Publications. 